\title{
Clinical pattern of hospitalized strokes in 28 hospitals in Indonesia
}

\author{
J. Misbach, A. Wendra
}

\begin{abstract}
Abstrak
Stroke merupakan penyebab kecacatan dan kematian yang semakin meningkat di Indonesia. Pola klinis stroke yang dirawat di rumah sakit belum banyak dilaporkan. Penelitian ini merupakan salah satu bagian dari ASNA Stroke Epidemiological Study yang bertujuan untuk meneliti pola klinis stroke di 7 negara ASEAN termasuk Indonesia dengan protokol yang sama. Dari 2065 penderita stroke akut yang dirawat di 28 rumah sakit di seluruh Indonesia, usia rata rata adalah 58,8 $\pm 13,3$ (SD) tahun, (rentangan 18-95 tahun). Dua belas koma sembilan persen berusia dibawah 45 tahun, dan 35,8\% diatas 65 tahun. Pria lebih banyak dari wanita. Waktu tiba di rumah sakit rata rata 48,5 $\pm 98,8$ jam (berkisar 1-968 jam) setelah serangan stroke. Sebagian besar tiba di rumah sakit di atas 6 jam setelah serangan. Alasan keterlambatan ini antara lain ketidaktahuan (56,3\%) dan kesulitan transportasi (21.5\%). Gejala yang paling menonjol adalah kelumpuhan dan gangguan bicara / bahasa. Faktor resiko tersering adalah hipertensi, penyakit jantung, merokok dan diabetes mellitus. Stroke berulang dijumpai pada sekitar $20 \%$ kasus. Jenis stroke terbanyak adalah stroke iskemik. Sebagian besar keluar rumah sakit dalam keadaan hidup dan membaik.
\end{abstract}

\begin{abstract}
Stroke is the increasing cause of morbidity and mortality in Indonesia. Data on clinical pattern of hospitalized Indonesian stroke patients is still not available. This study is a part of ASEAN Neurological Association (ASNA) Stroke Epidemiological Study aimed to investigate clinical profile of stroke in 7 ASEAN countries with the same protocol. From 2065 acute stroke patients admitted to 28 hospitals all over Indonesia, mean age was $58.8 \pm 13.3$ (SD) year (range: $18-95$ years). $12.9 \%$ were younger than 45 years, and $35.8 \%$ were older than 65 years. There were more men than women. Mean admission time was $48.5 \pm 98.8$ hours (range: $1-968$ hours). Most of them arrived at hospital more than 6 hours from the onset of stroke. The reasons for delayed admission were unawareness of stroke symptoms and long distance transportation. The most frequent stroke symptoms were motor disability. The most common risk factors were hypertension, heart diseases, cigarette smoking and diabetes mellitus. Recurrent stroke was found in nearly $20 \%$ patients. Ischemic stroke was the most frequent and the majority of the study subjects were discharged alive and improved.
\end{abstract}

Keywords : Stroke, clinical pattern, hospital-based study

Stroke is still the major cause of death and disabilities in developed countries, although recent epidemiological data showed a decreasing tendency of stroke mortality in those countries.' Indonesia as a developing countries with the population of more than 200 million people (the fourth largest population of the world) has little documented nation-wide data of stroke epidemiology, either hospital or community-based statistics. A limited hospital-based stroke survey revealed the growing tendency of stroke cases especially in urban hospitals in Jakarta. ${ }^{2}$ The availability of accurate stroke data are very important for national stroke combating programs all over Indonesia. This is the first large scale hospital-based stroke study involving the urban and rural areas in Indonesia. This study

Department of Neurology, Faculty of Medicine University of Indonesia/Dr. Cipto Mangunkusumo Hospital, Jakarta, Indonesia is a part of ASNA Stroke Epidemiological Study performed in seven ASEAN member Countries by ASNA Standing Committee For Stroke, from October 1996 until March 1997.

This article presents descriptively the demographic characteristics, clinical pattern, risk factors, type of stroke, arrival time, length of hospital stay and hospital discharge status of stroke patient in Indonesian population.

\section{METHODS}

Over a 6-month period from October 1996 to March 1997, we prospectively evaluated consecutive series of acute stroke patients admitted to 28 hospitals all over Indonesia. These hospitals represented most of the areas with dense population in Indonesia involving Java, Sumatera, Kalimantan and Sulawesi island. Thir- 
teen hospitals located in Jakarta and 15 hospitals were outside Jakarta. The participating hospitals consisted of 14 University-affiliated hospitals and 14 private or semi private hospitals in urban areas.

Diagnosis of stroke was made clinically by participating neurologists in those hospitals using the World Health Organization criteria, i.e. "rapid developing clinical signs of focal or global disturbances of cerebral function lasting more than 24 hours or leading to death with no apparent causes other than that of vascular origin". If CT scan is available, it should be done for confirmation.

All the subjects were assesed by participating neurologists and the following parameters were noted: demographic characteristics (age, sex, and etc.), hospital arrival time, reasons for delayed admission (more than six hours), clinical features, risk factors, type of stroke (by CT Scan), length of hospital stay and hospital discharge status.

Clinical data were stored in a preprepared floppy disk and descriptive statistics were applied using Statistical Program For Social Science (SPSS) 6.2 for Windows 95.

\section{RESULTS}

\section{Demographic characteristics}

During the period of the study, 2065 patients with acute stroke have been evaluated. Mean age was $58.8 \pm 13.3$ years (ranged $18-95)$, higher in women $(60.4 \pm 13.8$ years) than in men $(57.5 \pm 12.7$ years). The age distribution showed that $12.9 \%$ of the stroke patients were younger than 45 years old and $35.8 \%$ above 65 years. The sex distribution showed a slight prevalence of men (53.8\% vs $46.2 \%$ ). (Table 1 )

\section{Hospital admission time}

The mean time between onset of symptoms and hospital arrival was $48.5 \pm 98.8$ hours (ranged $1-968$ hours). Cumulatively, $21.1 \%$ of the patients were admitted within 3 hours, $32.7 \%$ within 6 hours, $44.8 \%$ within 12 hours and $50.2 \%$ within 24 hours from stroke onset. (Table 1)

The reason for delayed admission were as follows : $56.3 \%$ unawareness of having a stroke, $21.5 \%$ transportation problems, $11.8 \%$ taking traditional medicine, $4.2 \%$ visiting traditional healer and $6.2 \%$ unknown (Table 2)
Table 1. Characteristics of study subjects

\begin{tabular}{|c|c|}
\hline No. of patients & 2065 \\
\hline Mean age, y (SD) & $58.8(13.3)$ \\
\hline$<45$ & $12.9 \%$ \\
\hline $45-65$ & $50.5 \%$ \\
\hline$>65$ & $35.8 \%$ \\
\hline Sex, M/F & $1108 / 944$ \\
\hline Mean Admission Time, $h$ (SD) & $48.5(98.8)$ \\
\hline$<3 \quad h$ & $21.1 \%$ \\
\hline $3-6 \quad h$ & $11.6 \%$ \\
\hline $6-12 h$ & $12.1 \%$ \\
\hline $12-24 h$ & $5.4 \%$ \\
\hline$>24 \quad h$ & $49.8 \%$ \\
\hline Mean Length of hospital stay, d (SD) & $10.9(9.6)$ \\
\hline $1-7 \quad d$ & $42.8 \%$ \\
\hline $7-21 d$ & $46.1 \%$ \\
\hline $21-28 d$ & $5.6 \%$ \\
\hline$>28 \quad d$ & \\
\hline
\end{tabular}

Table 2. Reasons for delayed admission

\begin{tabular}{lr}
\hline No. of delayed patients & 1385 \\
Unawareness of having a stroke & $56.3 \%$ \\
Transportation problem & $21.5 \%$ \\
Taking traditional medicine & $11.8 \%$ \\
Visiting traditional healer & $4.2 \%$ \\
Unknown & $6.2 \%$ \\
\hline
\end{tabular}

\section{Signs and Symptoms}

Of the 2065 stroke patients, motor disability was the most prominent clinical feature $(90.5 \%)$ followed by headache $(39.8 \%)$, dysarthria $(35.2 \%)$, sensory disability $(27.3 \%)$, vomiting $(22.3 \%)$ and dysphasia $(15.6 \%)$ and the less frequent sign was carotid bruit $(0.3 \%)$. The other clinical features were summarized in Table 3.

Table 3. Clinical features of the stroke patients

\begin{tabular}{llr}
\hline Symptoms and signs & $\mathrm{n}$ & \multicolumn{1}{c}{$\%$} \\
\hline Motor disability & 1865 & 90.5 \\
Sensory disability & 562 & 27.3 \\
Visual disorders & 78 & 3.8 \\
Dysarthria & 724 & 35.2 \\
Dysphasia & 321 & 15.6 \\
Headache & 819 & 39.8 \\
Migraine & 9 & 0.4 \\
Vomiting & 459 & 22.3 \\
Vertigo & 196 & 9.5 \\
Unconscious & 196 & 9.5 \\
Seizure & 185 & 9.0 \\
Dysequilibrium & 79 & 3.8 \\
Carotid bruit & 7 & 0.3 \\
Carotid stenosis & 14 & 0.7 \\
\hline
\end{tabular}




\section{Risk Factors}

The most common risk factors for stroke in our study were hypertension (73.9\%). Thirty one point five percent of the hypertensive stroke patients were treated, $33.5 \%$ untreated and $8.9 \%$ diagnosed after admission. Smoking was the second most frequent risk factor $(20.4 \%)$ and $13.5 \%$ of them were recent smokers. The other major risk factors were prior stroke, ischemic heart disease and diabetes mellitus $(19.9 \%, 19.9 \%$ and $17.3 \%$, respectively). Seven point two percent of the diabetic stroke patients were treated, $5.2 \%$ untreated and $4.9 \%$ diagnosed after admission. The mean serum cholesterol level was $209.3 \pm 55.8 \mathrm{mg} \%$ (range 50 855 ) and $37.2 \%$ below $200 \mathrm{mg} \%, 26.0 \%$ in the range of $200-250 \mathrm{mg} \%$ and only $16.4 \%$ above $250 \mathrm{mg} \%$. Mean hematocrit value was $40.0 \pm 6.4$ vol \% (range 30 - 53) and $1.7 \%$ of the subjects had the hematocrit above 50 vol\%. (Table 4 )

Table 4. Risk factors of 2057 study subjects

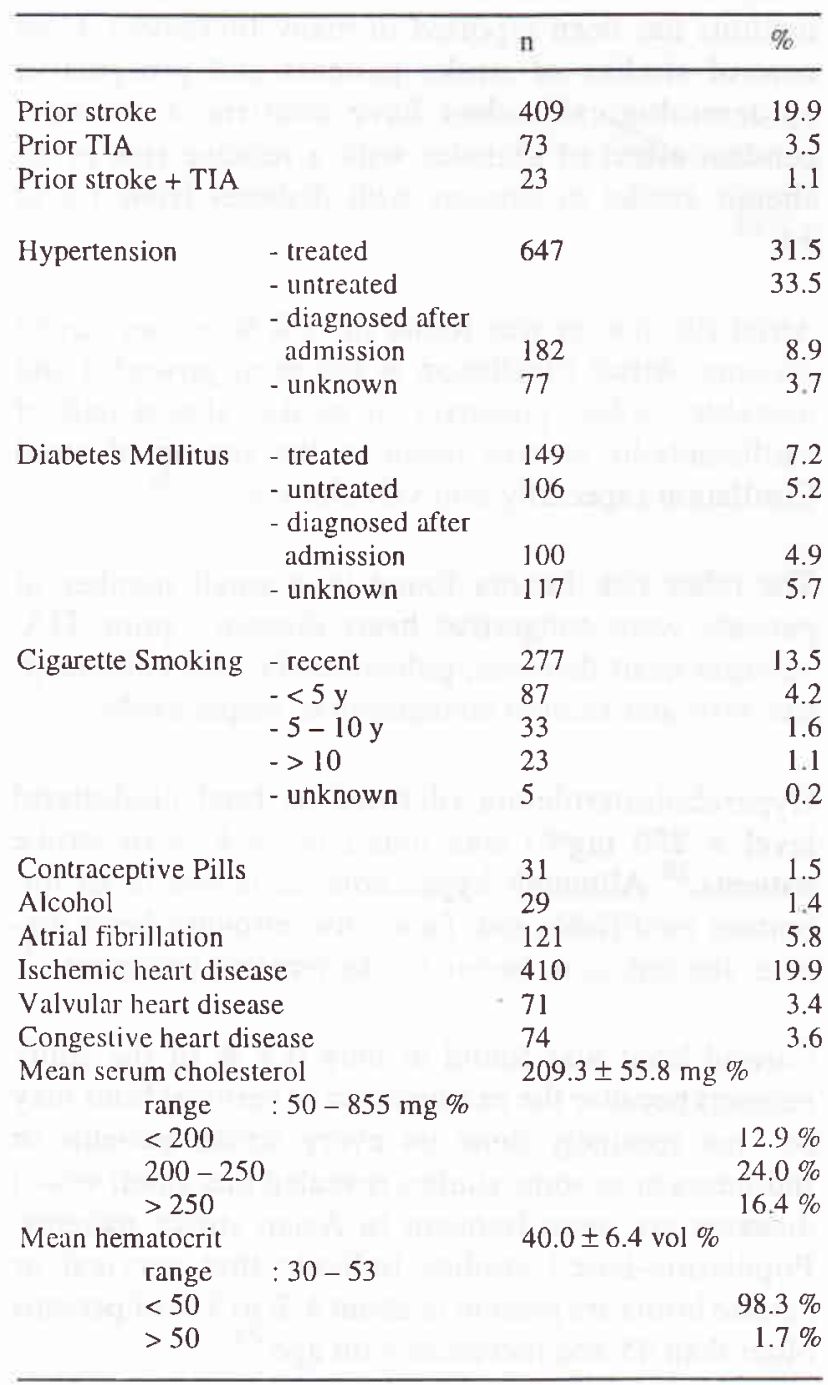

\section{Classification of stroke}

CT scan was done on $61.9 \%$ of the study patients and the mean time from onset to $\mathrm{CT}$ was $2.9 \pm 3.9$ day (median 1.0 and range $1-48$ day). The diagnostic classification based on CT finding, were non lacunar anterior circulation $(27.0 \%)$, lacunar $11.7 \%$, intracerebral hemorrhage $(18.5 \%)$, non lacunar posterior circulation $4.2 \%$, subarachnoid hemorrhage (1.4\%) and $38.1 \%$ undetermined (without CT).

\section{Hospital discharge status}

Table 5 shows that $56.9 \%$ of our study patients were alive-with improved condition whereas $4.3 \%$ patients had a worsening condition.

The overall mortality of the stroke patients was $23.3 \%$. The death rate was higher in hemorrhagic $(28.4 \%)$ than in ischemic stroke $(21.2 \%)$. The patient with non lacunar anterior circulation showed higher mortality $(15.2 \%)$ than patients with posterior circulation $(2.5 \%)$, while the lacunar infarction patients showed a very low death rate $(3.5 \%)$.

Table 5. Type of stroke and hospital discharge status of the study subjects

\begin{tabular}{lrr}
\hline Total subjects & 2057 & \\
No. of patients with CT Scan & 1274 & $(61.9 \%)$ \\
- abnormal & 1102 & $(53.6 \%)$ \\
- normal & 172 & $(8.3 \%)$
\end{tabular}

Type of stroke

- lacunar

$11.7 \%$

- non lacunar anterior circulation $\quad 27.0 \%$

- non lacunar posterior circulation $\quad 4.2 \%$

- subarachnoid hemorrhage $\quad 1.4 \%$

- lobar hemorrhage $\quad 8.8 \%$

- ganglionic hemorrhage $\quad 7.1 \%$

- brainstem hemorrhage $\quad 1.7 \%$

- cerebellum hemorrhage $\quad 0.9 \%$

- unknown (without CT) $\quad 38.1 \%$

Hospital discharge status

$\begin{array}{lr}\text { - alive - improved } & 56.9 \% \\ \text { - alive - unchanged } & 1.6 \% \\ \text { - alive - worsened } & 4.3 \% \\ \text { - alive status not recorded } & 5.1 \% \\ \text { - dead } & 23.3 \% \\ \text { - unknown } & 9.7 \%\end{array}$

\section{Length of hospital stay}

Overall mean length of hospital stay was $10.9 \pm 9.6$ days (range $1-96$ days). For those surviving, the mean 
length of hospital stay was 11 days for ischemic stroke and 17 days for hemorrhagic stroke.

\section{DISCUSSION}

Most of the hospitalized stroke patients in this study were in the age group of 45-65 years with the slight prevalence of men. Stroke in the young adults and in the old age people comprised of $12.9 \%$ and $35.8 \%$ respectively. This findings were not so different from the western literatures ${ }^{3-6}$ or some Asian countries. ${ }^{7,8}$

The majority of stroke patients arrived at hospitals more than six hours after stroke onset and only onefifth of the patients arrived within less than six hours. The reasons for delayed admission were unawareness of having a stroke and transportation problems. This fact showed that most of our people were not familiar with stroke symtoms and unaware of the emergency of this brain attack. Some foreign investigations on the arrival time of stroke also showed the same problems. It was concluded that community education for the early sign of stroke and ambulance service for quick hospitalisation have the key role in saving the patients. Anticipation of the thrombolysis and neuroprotective therapy for stroke will give best results if it is done within 3 hours from stroke onset. ${ }^{7-13}$

\section{Clinical Features}

Clinical features of our stroke patients showed motor disability as a prominent clinical feature followed by headache, dysarthria, sensory disorders and dysphasia respectively. This findings showed the importance of physical rehabilitation and speech therapy for Indonesian which must be done intensively and as early as possible in accordance with the clinical stability, in order to improve the quality of life and to avoid the severe disability as a sequelae of stroke. Headache is a common symptom in stroke and it was found in nearly $40 \%$ of the stroke patients in this study. Vestergaard $\mathrm{K}$ revealed that headache occurred in $50 \%$ of patients with intracerebral hemorhage, in $26 \%$ with infarction, and in $15 \%$ of patients with lacunar stroke. ${ }^{15}$ Further study is required to investigate headache characteristics in Indonesian stroke patients.

\section{Risk factors}

Hypertension was the most prominent risk factor (73.9\%) and almost half of the hypertensive stroke patients were not treated. Hypertension as a strong risk factor for stroke was undebatable. Many studies showed the consistent close relationship between the hypertension and the occurrence of stroke. ${ }^{15-19}$

Smoking is the second most frequent risk factor in Indonesian stroke patients and several studies showed that cigarette smoking is closely associated with the occurrence of cerebrovascular disease ${ }^{20}$ and it has been considered to be an independent modifiable risk factor. $^{21}$

Ischemic heart disease was found in $19.9 \%$ of the study subjects. In Framingham Study, if multivariate analy sis was used, risk of stroke was increased twofold in the presence of coronary heart disease and threefold with electrocardiographic left ventricular hypertrophy. So, prevention of these risk factors represents a cornerstone of cardioembolic stroke prevention. ${ }^{22}$

Diabetes mellitus was found in $17.3 \%$ of our stroke patients. Most of the diabetic patients were unproperly controled. Association between stroke and diabetes mellitus has been reported in many literatures. Case control studies of stroke patients and prospective epidemiological sudies have confirmed an independent effect of diabetes with a relative risk of ischemic stroke in persons with diabetes from 1.8 to $3.0^{25}$

Atrial fibrillation was found in $5.8 \%$ of our stroke patients. Atrial fibrillation is the most powerful and treatable cardiac precursor of stroke, almost half of cardioembolic strokes occur in the setting of atrial fibrillation especially non valvular type. ${ }^{23,24}$

The other risk factors found in a small number of patients were congestive heart disease, prior TIA, valvular heart diseases, policythemia, oral contraceptive pills and alcohol consumption, respectively.

Hypercholesterolemia (defined as total cholesterol level $>250 \mathrm{mg} \%$ ) was found in $16.4 \%$ of stroke patients. ${ }^{26}$ Although hypercholesterolemia is an important modifiable risk factor for coronary heart disease, the link to ischemic stroke remains uncertain. ${ }^{27}$

Carotid bruit was found in only $0.3 \%$ of the study subjects because the examination of cervical bruit may be not routinely done on every stroke patients in Indonesia or as some studies revealed that small vessel diseases are more frequent in Asian stroke patients. Population-based studies indicate that cervical or carotid bruits are present in about $4 \%$ to $5 \%$ of persons older than 45 and increases with age. ${ }^{28}$ 


\section{Stroke recurrence}

Stroke recurrence was found in $19.9 \%$ of patients. This finding showed that recurrent stroke was higher in Indonesian stroke patients compared with that reported in some literatures. 29

\section{Type of stroke}

Because CT Scans were not available in all hospitals, especially in rural areas in Indonesia, only $61.9 \%$ of the study patients were confirmed by CT scan. Ischemic strokes accounted for $42.9 \%$ and these included lacunar infarction ( $11.7 \%$ ), non lacunar anterior circulation $(27.0 \%)$ and non lacunar posterior circulation $(4.2 \%)$. Hemorrhagic stroke was detected in $18.5 \%$, whereas subarachnoid hemorrhage was rare $(1.4 \%)$. About $39.1 \%$ of patients were with undetermined cause of stroke because CT scans were not done. The frequency of stroke type or subtype in this study was rather low compared with the other investigator. ${ }^{30}$ This might be caused by the different classification used by the investigators and large number of patients without CT scan investigation in our study.

\section{Stroke outcome}

Although most of stroke patients were discharged alive and improved from the hospitals, however, hospital mortality was found in $21.2 \%$ for ischemic stroke and $28.2 \%$ for hemorrhagic stroke. This data showed higher results than in western literature. ${ }^{31,32}$

\section{Length of hospital stay}

Mean length of stay of survived stroke victims was 11 days for ischemic stroke and 19 days for hemorrhagic stroke. The result revealed that non-medical bed-days were low in most of the hospitals in Indonesia because majority of our patients were low social economy and no insurance coverage. Mayo et al (1997) reported that non-medical bed-days were high in stroke patients with health insurance status and high social economic strata. ${ }^{33}$

In conclusion, we have presented the clinical data on stroke profile involving most of the hospitals in Indonesia and this descriptive data will be the starting point of further investigations on various nation-wide stroke researches in Indonesia.

\section{Acknowledgments}

We wish to thank the participating neurologists as follows :
Jakarta : Dr. Andradi S, Dr. Teguh Ranakusuma, Dr. Wendra Ali, Dr. A.Munandar, Dr. Rumaléan Dr.Anwar Wardy, Dr. Ayub, Dr. Surjo Atmodjo, Dr. Sukono, Dr. Susesty, Dr. Jusuf Misbach, Dr.Edy Sunarto; Medan : Dr. Darulkutni; Banda Aceh :Dr. Syahrul; Padang : Dr.Basjiruddin; Palembang: Dr.Margono; Bandung: Dr.Dede Gunawan, Dr. Adelyna Yaumir; Semarang: Dr.Sudomo Surabaya: Dr. Fauziah Baosier, Yogyakarta: Dr. Rusdi Lamsudin, Bali: Dr. Wayan Kondra; Ujung Pandang: Dr.Amiruddin; Manado: Dr. Siwi; Pontianak: Dr. Melani.

\section{REFERENCES}

1. WHO MONICA Project, Principal Investigators. The World Health Organization MONICA Project (monitoring trends and determinants in cardiovascular disease): a major international collaboration. J Clin Epidemiol 1988 ; 41 : 105-14.

2. Misbach J, Suryamiharja A, Malik MS , Sandia IN. Pattem of Hospitalized Stroke in 10 Hospitals in Jakarta. Survey Report by Dept. of Health of Indonesia, 1995.

3. Gillum RF. The epidemiology of stroke in Native Americans. Stroke. 1995;26:2222-7

4. Bogousslavsky J, Melle GV, Regli F. The Lausanne Stroke Registry: an analysis of 1000 consecutive patients with first stroke. Stroke. 1988;19:1083-92.

5. Caplan LR, Kargman DE, Gu Q, Zamanillo MC. Race, sex and occlusive cerebrovascular disease: a review. Stroke. 1986; 17:648-55.

6. Chambers BR, Donnan GA, Baldin PF. Pattern of stroke: an analysis of the first 700 consecutive admisssion to the Austin Hospital stroke unit. Aust N Z J Med. 1983;13:57-64

7. Shi F, Hart RG, Sherman DG, Tegeler CH. Stroke in the People's Republic of China. Stroke 1989;20:1581-5.

8. Hu,HH, Sheng WY, Chu FL, Lan CF, Chiang BN. Incidence of Stroke in Taiwan. Stroke 1992;23:1237-41.

9. Turney TM, Garraway WM, Whisnant JP. The natural history of hemispheric and brainstem infarction in Rochester, Minnesota. Stroke $1984 ; 15$ : 790 - 94.

10. Gogelholm R, Murros K, Rissanen A, Ilmavirta M. Factors delaying hospital admission after acute stroke. Stroke. 1996 ; $27: 398-400$.

11. Anderson NE, Board JB, Bonita R. Delays in hospital admission and investigation in acute stroke. BMJ. 1995;311:162.

12. Feldmann E, Gordon N, Brooks JM, Fayd PB, Sawaya KL, Nazareno F, Levine SR. Factors associated with early presentation of acute stroke. Stroke. $1993 ; 24: 1805-10$.

13. Harper GD, Haigh RA, Potter JF, Castleden CM. Factors delaying hospital admission after stroke in Leincastershire. Stroke. $1992 ; 23: 835-838$.

14. Biller J, Shephard A, Adams HP. Delay time between onset of ischemic stroke \& hospital arrival. Neurology. 1992;42 (suppl 3):250. Abstract.

15. Vestergaard K, et al. Headache in Stroke. Stroke. 1993; 24:1621-24

16. Rutan GH, Kuller LH, James PH, et al,. Mortality associated with diastolic hypertension and isolated systolic hyperten- 
sion among men screened for the Multiple Risk Factor Intervention Trial. Hypertension. 1988;77:504-14.

17. Broderick JP. Intracerebral hemorrhage. In: Gorelick PB, Alter M, eds. Handbook of Neuroepidemiology. New York. NY: Marcel Dekker Inc; 1994

18. Mac mahon S, Rodgers A. The epidemiologycal association between blood pressure and stroke: implication for primary and secondary prevention. Hypertension. 1994; 17(suppl 1): S23-S32.

19. Whisnant JP. Effectiveness versus efficacy of treatment of hypertension for stroke prevention. Neurology. 1996;46: 301-7.

20. Dyken ML, Wolf PA, Barnett HJM, Bergan JJ, Haa WK, Kannel WB, Kuller L, Kurtzke JF, Sundt TM. Risk factor in stroke. Stroke. 1984;15:1105-11.

21. Wolf PA, D'Agustino RB, Kannel WB, Bonita R, Belanger AJ. Cigarette smoking as a risk factor for stroke : the Framingham Study. JAMA. 1993;269;232-6.

22. Shinton R, Beever G, Meta-analysis of relation between cigarette smoking and stroke : BMJ. 1989;298:789-94.

23. Wolf PA, Abbot RD, Kannel WB. Atrial fibrillation as an independent risk factor for stroke: the Framingham Study. Stroke. 1991;22;983-8.

24. Wolf PA, Benyamin EJ, Belanger AJ, Kannel WB, Levy D, D'Agostino RB, Secular trends in the prevalence of atrial fibrillation as an independent risk factor for stroke: the Framingham Study. Am Heart J. 1996;131;790-5.
25. Burchfiel CM, Curb JD, Rodriquez BL, Abbot RD, Chiu D, Yano K. Glucose intolerance and 22 year stroke incidence; Honolulu Heart Program. Stroke. 1994;25:951-7.

26. Iso H, Jacobs DR Jr, Wenworth D, Neaton JD, Cohen JD. Serum cholesterol levels and six-year mortality from stroke in 350977 men screened for the multiple risk factor intervention trial. N Eng J Med. 1989;320:904-10

27. Summary of the National Chlolesterol Education Program (NCEP) Adult Treatment Panel II report. JAMA. 1993; 269:3015-23.

28. Wolf PA, Kannel WB, Sorlie P, Mc Namara P. Asymptomatic neck bruits. N. Eng J Med. 1986;315:860-5.

29. Sacco RL, Wolf PA, Kannel WB, Mc Namara PM. Survival and recurrence following stroke: the Framingham study. Stroke. 1982;13:290-5

30. Bamford J, Sandercock P, Dennis M, Bum J, Warlow C. Classification and natural history of clinically indentifiable subtypes of cerebral infarction. Lancet $1991 ; 337: 1521$ 26.

31. Bamford J, Dennis M, Sandercock P, et al. The frequency, causes and timing of death within 30 days of a first stroke: the Oxfordshire Stroke Project. J. Neurol Neurosurg Psychiatry. 1990;53:824-9.

32. Ellekjaer H, Holmen J, Indredavik B, et al. Epidemiology of Stroke in Innherred, Norway, 1994 to 1996: Incidence and 30-day Case fatality Rate. Stroke. 1997;28:2180-4.

33. Mayo NE, Wood-Dauphinee S, Gayton D, et al. Nonmedical Bed-Days for Stroke Patients Admitted Acute Care Hospitals in Montreal, Canada. Stroke. 1997;28:543-9. 